УДК 66.021.001.57:56/59.004.18

DOI https://doi.org/10.15673/swonaft.v84i1.1865

\title{
ЕКСПЕРИМЕНТАЛЬНІ ДОСЛІДЖЕННЯ ПРОЦЕСУ ПЕРЕРОБКИ КІСТОЧКОВИХ ПЛОДІВ В НАТИВНОМУ СТАНІ В УМОВАХ ВІДЦЕНТРОВОГО ПОЛЯ В РЕЖИМІ БЕЗПЕРЕРВНОЇ ДІЇ
}

\author{
Кепін М.І., канд. техн. наук, доцент, Попов В.О., магістр \\ Одеська національна академія харчових технологій
}

\begin{abstract}
Анотація. Наведені результати експериментальних досліджень процесу переробки слив сорту “Угорка Домашня” в нативному стані в режимі безперевної дї в умовах відцентрового поля з використанням нерухомої перфорованої оболонки та лопатевого ротора, який виконує обертовий рух.

Проаналізовано діючі способи та обладнання для переробки кісточкової сировини з метою розділення на напівфабрикат та відходи як в режимі ичклічної дї (кісточковибивні машини) так і в режимі безперервної дї.

Виконанні дослідження міцності шкірочки цілих плодів та запасаючої тканини (м'якоті) на прокол, проаналізовано біологічний зв'язок між кісточкою і запасаючою тканиною. Показано, щуо такий зв'язок має місие, в основному, на ділянці судинно-волокнистий пучків кожного плоду.

В залежності від виду плодів та сортів кожного виду міцність покривних тканин може значно відрізнятись між окремими ділянками поверхні плодів, щзо впливає на їх поведінку при переробиі в умовах відиентрового поля. Для плодів з рівномірною характеристикою міиності тканин по всьому об'ємі характерні стабільні режими переробки.

Проаналізовано вплив форми плодів та кісточок на процес переробки. Для плодів, форма яких наближена до правильної (округла, овальна) прочес відокремлення м'якоті від кісточок відбувається в більш стабільному режимі в порівнянні з плодами, форма яких відрізнясться від правильної.

Особливої уваги заслуговує форма кісточок, від якої залежить стабільність процесу переробки. Так, для кісточок з округлою та овальною формами характерні більш стабільні режими в порівнянні із витягнутими формами. Характерною відмінністю при переробиі плодів з такою формою кісточок $є$ стан перед атакуючою поверхнею лопаті та перфорованою поверхнею, при якому відокремлення м'якоті від кісточки відбувається тільки з однієї сторони плоду.

Встановлено зв'язок між кутовою швидкістю лопатей та кількістю м'якоті, яка не відокремилась від кісточок. На рівні гіпотез виконано аналіз причин руйнування кісточок за межами рекомендованих режимів переробки. За результатами експериментальних досліджень рекомендовано режим переробки, які відповідають мінімальним втратам м'якоті.
\end{abstract}

Ключові слова: плоди кісточкових культур, міцність тканин, форма плодів і кісточок, переробка.

\section{EXPERIMENTAL STUDIES OF THE PROCESSING PROCESS OF STONE FRUITS IN THE NATIVE STATE IN THE CONDITIONS CENTRIFUGAL FIELD IN CONTINUOUS MODE}

\author{
Kepin M.I., Ph.D., Associate Professor, Popov V.O., Master \\ Odessa National Academy of Food Technologies
}

\begin{abstract}
The results of experimental studies of the process of "Ugorka Domashnya"plums in the native state processing in the mode of continuous action in a centrifugal field using a fixed perforated shell and a vane rotor that performs rotational motion are presented.

The current methods and equipment for processing of bone raw materials for the purpose of division into semifinished products and wastes both in the mode of cyclic action (bone-knocking machines) and in the mode of continuous action are analyzed.

The puncture strength of the whole fruit and the storage tissue (pulp) for the puncture was performed, and the biological relationship between the stone and the storage tissue was analyzed. It is shown that such a connection takes place mainly in the area of vascular-fibrous bundles of each fetus.
\end{abstract}




\section{Одеська національна академія харчових технологій ТЕОРЕТИЧНІ ТА ЕКСПЕРИМЕНТАЛЬНІ ДОСЛІДЖЕННЯ ГІДРАВЛІЧНИХ, ТЕПЛОВИХ ТА МАСООБМІННИХ ПРОЦЕСІВ}

Depending on the type of fruit and varieties of each species, the strength of the integumentary tissues can differ significantly between individual areas of the surface of the fruit, which affects their behavior during processing in a centrifugal field. Fruits with uniform characteristics of tissue strength throughout the volume are characterized by stable processing modes.

The influence of the shape of fruits and stones on the processing process is analyzed. For fruits that are close to the correct shape (round, oval), the process of separating the flesh from the stones is in a more stable mode compared to fruits whose shape differs from the correct one.

The shape of the bones deserves special attention, on which the stability of the processing process depends. Thus, bones with rounded and oval shapes are characterized by more stable modes compared to elongated shapes. A characteristic difference in the processing of stone-shaped fruit is the condition in front of the attacking surface of the blade and the perforated surface, in which the separation of the flesh from the stone occurs only on one side of the fruit.

The relationship between the angular velocity of the blades and the amount of pulp that has not been separated from the bones has been established. At the level of hypotheses, the analysis of the causes of bone destruction outside the recommended processing regimes was performed. According to the results of experimental studies, a processing regime is recommended that corresponds to the minimum loss of pulp.

Key words: stone fruit fruits, tissue strength, fruit and stone shape, processing.

Вступ. Основними напрямками вдосконалення технологій переробки плодоовочевої сировини є розширення асортименту, підвищення якості, ресурсозбереження. При цьому необхідні комплексна переробка вторинних сировинних ресурсів, створення безвідходних та екологічно чистих виробництв, впровадження у виробництво перспективних поточних технологій.

У зв'язку з погіршенням екологічної і соціальної обстановки особливого значення набуває створення раціональних безвідходних технологій виробництва консервованої продукції, що передбачають максимальне збереження нативних біологічно активних речовин сировини. 3 цієї точки зору анатомо-морфологічна будова плодів кісточкових культур в повній мірі дозволяє використовувати вказані напрямки технології переробки.

Аналіз літературних джерел. Перфоровані оболонки, як складова машин та апаратів, широкого використання набули в багатьох переробних галузях харчової промисловості: цукровій, плодоовочевій, крохмале-патоковій, виноробній, консервній тощо [1 - 4]. Однією із основних функцій перфорованих поверхонь $є$ розділення харчових дисперсних систем як мінімум на дві фракції, одну з яких подають на подальшу переробку а інша являє собою складову відходів.

В залежності від умов проведення певного процесу перфоровані оболонки можуть знаходитись або в нерухомому стані, або в режимі обертового руху. Окремим випадком стосовно вказаних варіантів $\epsilon$ наявність вібраційного руху для обох випадків.

Рухомою силою процесу може бути обертовий рух оболонки, надлишковий тиск в робочому просторі при нерухомій оболонці та обертовий рух, наприклад, лопатевого ротора при нерухомій оболонці.

Останній варіант набув широкого використання на переробних підприємствах плодоовочевої сировини за допомогою протиральних машин класичного типу з консольним кріпленням лопатевого ротора, основною функцією яких, після попереднього подрібнення та термообробки багатьох видів плодів, $є$ розділення на напівфабрикат та відходи.

До таких видів відносять насіннєві культури (фрукти, овочі, баштанні культури), корене- та клубенеплоди, кісточкові плоди (абрикос, алича, вишні, сливи тощо). Останні перед протиранням розварюють 3 метою руйнування біологічних зв'язків між складовими плодів: шкірочкою та запасаючою тканиною (м’якоттю) та між м'якоттю і кісточками [4].

В залежності від вимог до кінцевого продукту, виду сировини, фізико-механічних та структурномеханічних властивостей окремих видів в протиральних машинах використовують нерухомі перфоровані оболонки (сита) з діаметрами отворів в діапазоні $(0,4 \ldots 7,0)$ мм. Рухомою силою процесу є обертовий рух лопатевого ротора.

Кісточковибні машини використовують виключно для переробки кісточкових культур, в яких кісточки легко відокремлюються від м'якоті, тобто, біологічних зв'язок або відсутній, або має локальний зв'язок.

Формулювання проблеми. На підприємствах харчової промисловості переробка плодів кісточкових культур здійснюється за двома основними напрямками: одержання продукції у вигляді цілих плодів (сушені та заморожені плоди, компоти) або продукцію, яка являє собою результат переробки плодів з використанням певних режимів згідно технологічних вимог до кінцевих продуктів: соки натуральні та купажовані освітлені та неосвітлені, концентровані соки, плодово-ягідні пюре, соуси, пасти, желе, консерви для дитячого та дієтичного харчування, фруктові порошки, які використовують у кондитерській, хлібобулочній і харчоконцентратній промисловості.

$$
\text { Наукові праці, Том 84, випуск } 1
$$


Одеська наиіональна академія харчових технологій

\section{ТЕОРЕТИЧНІ ТА ЕКСПЕРИМЕНТАЛЬНІ ДОСЛІДЖЕННЯ ГІДРАВЛІЧНИХ, ТЕПЛОВИХ ТА МАСООБМІННИХ ПРОЦЕСІВ}

Для виготовлення вказаних видів продукції використовують запасаючу тканину плодів (м'якоть) після попереднього вилучення кісточок з використанням різних способів і обладнання [5].

В роботі [6] подано результати експериментальних досліджень процесу переробки одиночних плодів без попередньої термообробки (в свіжому стані) з метою розділення на складові в умовах відцентрового поля 3 використанням перфорованих оболонок, діаметри отворів яких становили 2, 4, 6, 8 та 10 мм і нульовим кутом випередження лопатей. Необхідність проведення досліджень з одиничними плодами була пов'язана 3 відсутністю в літературних джерелах розумінням фізичної картини процесу відокремлення м'якоті від кісточок. У висновках вказані напрямки доцільності переробки плодів кісточкових культур без попередньої термообробки.

Наступним етапом переробки є дослідження процесу розділення кісточкової сировини у вихідному (нативному) стані на складові в режимі безперервної дії. Відмінною рисою при цьому є наявність двох складових руху у зв'язку із встановленням лопатей з певним кутом до вісі ротора (кутом випередження). Це обертовий рух плодів і рух вздовж робочих поверхонь лопатей та внутрішньою поверхнею перфорованої оболонки 3 одночасним відокремленням м'якоті від кісточок крайками отворів. У підсумку маємо рух плодів за гвинтовою лінію, стан яких змінюється від місця завантаження цілих плодів до розвантаження кісточок без м'якоті. Імовірно, на першому етапі до моменту руйнування шкірочки плоди під дією лопатей здійснюють обертовий рух. На другому - відбувається руйнування шкірочки з подальшим відокремленням м'якоті крайками отворів. На третьому - кісточки без м'якоті або з їі деякою часткою завдяки куту випередження лопатей транспортуються до місця розвантаження з робочого простору оболонки.

На підставі вказаної гіпотези поведінки предмету дослідження у наведених умовах відцентрового поля стає необхідність визначення режимів переробки, при яких процес переробки плодів є найбільш ефективним.

Мета роботи - дослідження динаміки переробки плодів кісточкових культур в умовах відцентрового поля з метою розділення на складові внаслідок поступового відокремлення м'якоті від кісточок крайками отворів перфорованої оболонки та встановити залежність втрат м'якоті від кутової швидкості лопатей.

Таким чином об'єкт дослідження є технологічний процес переробки плодів кісточкових культур в нативному стані на етапі підготовки сировини стосовно загального технологічного процесу виготовлення готової продукції.

Предмет дослідження - сливи сорту “Угорка Домашня”.

Експериментальна установка та методика досліджень

Для проведення експериментальних досліджень 3 метою відокремлення м'якоті від кісточок в полі відцентрових сил в режимі безперервної дії була розроблена експериментальна установка, функціональна складова якої подана на рис. 1.

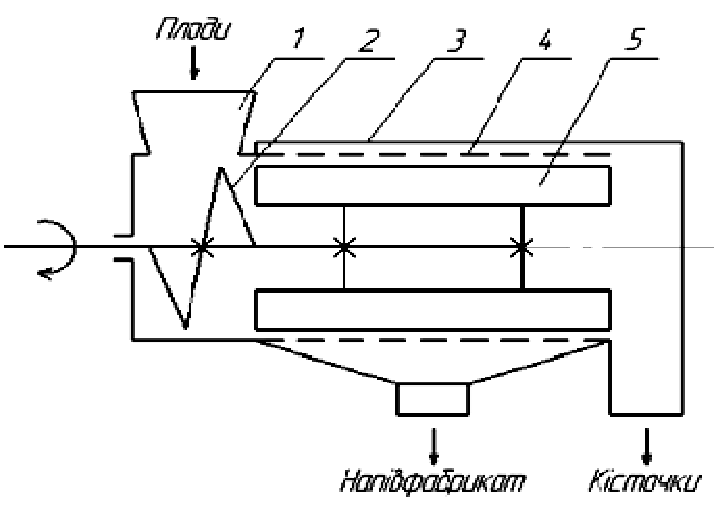

1 - завантажувальна воронка; 2 - шнек; 3 - кожух; 4 - перфорована оболонка; 5 -ротор лопатевий

\section{Рис. 1 - Схема експериментальної установки}

Установка складається із перфорованої оболонки, лопатевого ротора, який налічує шість лопатей з радіальним напрямком монтування та кутом випередження $2^{\circ}$, шнека для подачі плодів в робочий простір оболонки, завантажувальної воронки та кожуха з можливістю розвантаження напівфабрикату та кісточок за різними напрямками. 3 метою контролю завершення процесу переробки чергової партії плодів ділянку кожуха вилучення кісточок з робочого простору перфорованої оболонки було виконано з прозорого матеріалу.

Перфорована оболонка внутрішнім діаметром 140 мм і довжиною 180 мм співвісно монтувалась на приводному валові зі шнеком, крок якого становив 70 мм. Діаметр отворів перфорованої оболонки становив 8 мм, коефіцієнт живого перерізу - 0,4.

Наукові праці, Том 84, випуск 1 Scientific Works, Volume 84, Issue 1 
Одеська національна академія харчових технологій

\section{ТЕОРЕТИЧНІ ТА ЕКСПЕРИМЕНТАЛЬНІ ДОСЛІДЖЕННЯ ГІДРАВЛІЧНИХ, ТЕПЛОВИХ ТА МАСООБМІННИХ ПРОЦЕСІВ}

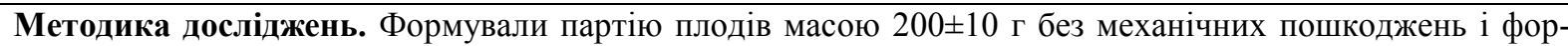
мою, яка відповідала вказаному сорту. Маса окремих плодів в партії коливалась в діапазоні $(9,5 \ldots 11,8)$ г, вміст кісточок в плодах становив $(8,4 \ldots 11,0) \%$, міцність покривних тканин на прокол цілих плодів колива-

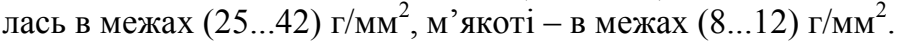

Кутову швидкість лопатей за допомогою частотного перетворювача моделі VFD037F43А потужністю 3,7 кВт варіювали на рівнях 83,73; 94,20; 104,67; 115,13; 125,60 $\mathrm{c}^{-1}$.

На кожному рівні встановлювали необхідну кутову швидкість, рівномірно завантажували чергову партію плодів і після завершення процесу переробки виключали електродвигун. На кожному рівні експерименти виконували в трикратній повторності.

Ефективність процесу переробки контролювали за кількістю м'якоті (залишкова м'якоть), яка не відокремилась від кісточок на кожному рівні (талб. 1).

Таблиия 1

\section{Середні значення кількості залишкової м’якоті, яка не відокремилась від кісточок}

\begin{tabular}{|c|c|}
\hline $\begin{array}{c}\text { Кутова швидкість } \\
\text { ротора, } \text { c }^{-1}\end{array}$ & $\begin{array}{c}\text { Кількість залишкової } \\
\text { м'якоті на кісточках, \% }\end{array}$ \\
\hline 83,73 & 25,64 \\
\hline 94,20 & 8,88 \\
\hline 104,67 & 5,66 \\
\hline 115,13 & 4,69 \\
\hline 125,60 & 1,59 \\
\hline
\end{tabular}

За результатам досліджень побудовану графічну залежність кількості м'якоті (ії втрат), яка не відокремилась на кожному рівні кутової швидкості лопатевого ротора (рис. 2).

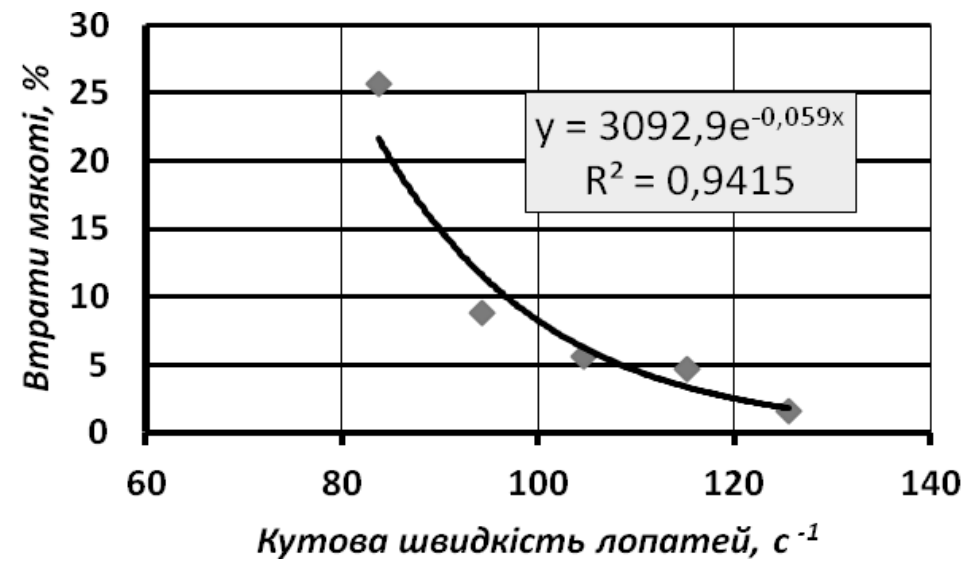

Рис. 2 - Залежність втрат м'якоті від кутової швидкості лопатей

Аналіз результатів дослідження. Аналіз експериментальних даних $є$ підтвердженням факту впливу кутової швидкості як основного фактора, який впливає на ефективність відокремлення м'якоті від кісточок [6], але наявність залишкової м'якоті на кісточках вказує не необхідність пошуку причин такого явища.

Причин наявності залишкової м'якоті на кісточках в певних діапазонах режимів переробки може бути декілька, основними з яких є: міцність покривних тканин (шкірочки) та м'якоті, форма плодів та форма кісточок.

В роботі [7] показано, що міцність покривних тканин кісточкових плодів суттєво відрізняється між собою і залежить від виду плодів, сорту в кожному виді, ступеня стиглості в залежності від орієнтації на дереві “північ-південь” (абрикоси, наприклад), загального ступеня стиглості (однорідність міцності шкірочки та м'якоті по всій поверхні деяких сортів кизилу, вишні, аличі) та міцності окремих ділянок поверхні (судинноволокнистий пучок: угорки деяких сортів, абрикоси). Наприклад, міцність покривних тканин на прокол слив

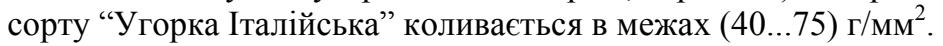

За результатами пошукових експериментів підтвердилась гіпотеза, що першочергове руйнування плодів має місце на ділянці з мінімальною міцністю і відокремлення м'якоті відбувається при відсутності обертового руху плоду до стану контакту оголеної поверхні кісточки з перфорованою поверхнею оболонки. 
В роботі [8] показано, що орієнтація плодів в умовах відцентрового поля при обертовому русі залежить від їх форми. Так, плоди овальної форми (деякі сорти кизилу, угорків, абрикосів) своєю біологічною віссю орієнтуються вздовж робочих поверхонь лопатей (рис. $3, a$ ), плоди, форма яких близька до округлої форми (деякі сорти вишень, черешень, аличі, абрикосів) під час обертового руху під дією лопатей орієнтуються випадковим чином. Плоди грушоподібної, яйцеоберненої та ін. форм в стадії рівноваги знаходяться в результаті контакту з поверхнею лопатей та поверхнею оболонки за двома точками.

Орієнтація кісточок, форма яких наближена до правильної (округла, овальна) аналогічна орієнтації цілих плодів подібних форм, але орієнтація кісточок, форма яких відрізняється від вказаних (абрикоси, угорки), залежить від площі, так званої, опорної поверхні однією із бокових поверхонь кісточки (рис. 3, б).
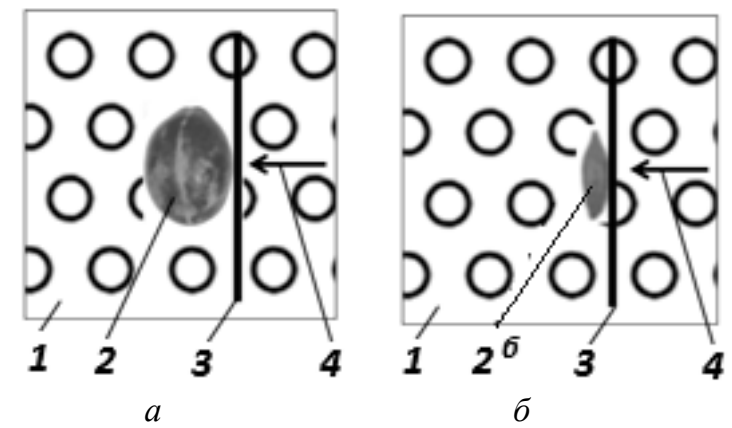

a: 1 - перфорована оболонка; 2 -плід; $2^{6}$-кісточка; 3 -лопать; 4 -напрямок руху лопаті

Рис. 3 - Оріснтація цілого плоду $а$ та кісточки б в умовах відцентрового поля внаслідок обертового руху лопатей.

На рис. 4 подано зразки плодів в стані, при якому відокремлення м'якоті від кісточки відбувається 3 однієї сторони на прикладі попередніх досліджень плоду абрикосу (рис. ..., а) та сливи (рис. ..., б) сорту, який використовували в зазначених експериментальних дослідженнях.
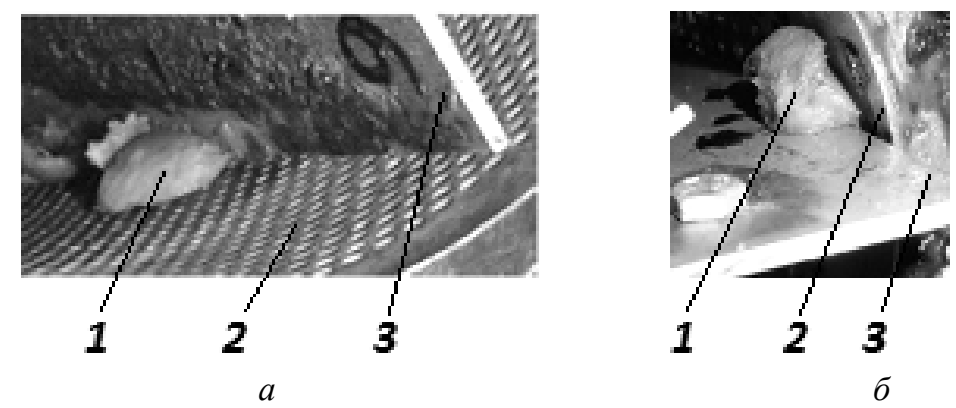

а-абрикосу; б-сливи сорту “Угорка Домашня”:

1 - фрагмент плоду; 2 - перфорована поверхня; 3 -лопать

Рис. 4 - Зразки плодів в стані з одностороннім відокремленням м'якоті від кісточок

На рис. 5 подано фрагменти плодів та кісточок за результатами досліджень.

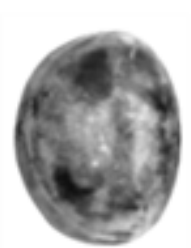

$a$

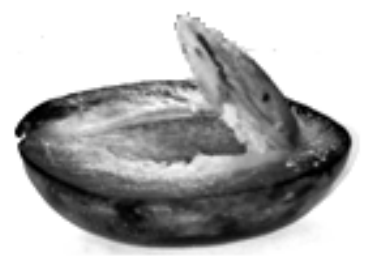

$\sigma$

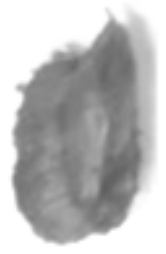

B

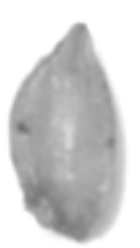

2
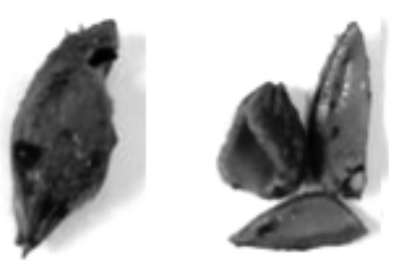

$\partial$

$a$ - плід; б - ділянка біологічного зв'язку між м'якоттю і кісточкою;

в - залишкова м'якоть на кісточціі; г - кісточка без м'якоті;

д - зразки зруйнованих кісточок

Рис. 5 - Зразки за результатами експериментальних досліджень 


\section{Висновки}

1. Ефективність переробки плодів кісточкових культур в нативному стані для розділення на напівфабрикат та відходи в полі відцентрових сил залежить від кутової швидкості лопатей, міцності як покривних тканин так і м'якоті, форми плодів та кісточок.

2. Підставою для вибору ефективних режимів роботи плодів кісточкових культур повинна бути інформація за анатомо-морфологічними характеристиками стосовно кожного виду та сорту в кожному виді.

3. Причина руйнування кісточок пов'язана, в першу чергу, їх будовою за формою. Для кісточок витягнутої форми (сливи, деякі сорти абракосів) характерні загострені кінцівки. Це підвищує ризик їх потрапляння в отвори оболонки при їх неправильній орієнтації в робочому просторі, що приводить до руйнування лопатями при їх обертовому русі. Одним із напрямків усунення факту руйнування полягає в зменшені діаметрів отворів перфорованої оболонки.

4. Одним із напрямків зменшення втрат м'якоті, яка не відокремилась від кісточок, можлива реконструкція лопатей, що приведе до зміни застійного стану плодів під час переробки.

\section{References}

1. Zaichyk, Ts.F. (2004). Tekhnolohycheskoe oborudovanye vynodelcheskykh predpryiatyi M.:DeLy prynt.

2. Huloho, I.S. (Ed.). (2001). Obladnannia pidpryiemstv pererobnoi ta kharchovoi promyslovosti. K.: Nova knyha.

3. Shkoropad, D. E., Novykov, O. P. (1987). Tsentryfuhy y separatorы dlia khymycheskykh proyzvodstv. M.: Khymyia.

4. Hladushniak, A.K. (1985). Teoriya i praktika protiraniya i finishirovaniya rastitel'nogo syr'ya: Dys... d-ra tekhn. nauk. Odessa.

5. Amynov, M.S., Dykys, M.Ia., Malskyi, A.N., Hladushniak, A.K. (1986). Tekhnolohycheskoe oborudovanye konservnbikh zavodov. M.: Ahropromyzdat.

6. Kepin, M. I., Kyrylov, V.Kh. (2016). Teoretychne obgruntuvannia protsesu pererobky plodiv kistochkovykh kultur. Pyshchevaia nauka y tekhnolohyia, 10(3), 82-86.

7. Kepin, M.I., Kyrylov, V.Kh. (2019). Matematychne modeliuvannia napruzhenoho stanu plodu kistochkovykh kultur pry yoho obrobtsi na perforovanii poverkhni v poli vidtsentrovykh syl. Naukovi pratsi, 83(2), 112-120.

8. Kepin, M.I. (2016). Analiz stanu plodiv kistochkovykh kultur pry yikh pererobtsi na perforovanii poverkhni v poli vidtsentrovykh syl. Pyshchevaia nauka y tekhnolohyia, 10(4), 67-72.

Отримано в редакцію: 10.07.2020

Прийнято до друку: 06.12.2020
Received: 10.07.2020

Approved: 06.12.2020 